\title{
Oceanic heterotrophic bacterial nutrition by semilabile DOM as revealed by data assimilative modeling
}

\author{
Ya-Wei Luo ${ }^{1,2,6, *}$, Marjorie A. M. Friedrichs ${ }^{3}$, Scott C. Doney ${ }^{4}$, \\ Matthew J. Church ${ }^{5}$, Hugh W. Ducklow ${ }^{1,2}$ \\ ${ }^{1}$ The Ecosystems Center, Marine Biological Laboratory, 7 MBL Street, Woods Hole, Massachusetts 02543, USA \\ ${ }^{2}$ Department of Ecology and Evolutionary Biology, Brown University, Providence, Rhode Island 02912, USA \\ ${ }^{3}$ Virginia Institute of Marine Science, College of William and Mary, PO Box 1346, Gloucester Point, Virginia 23062, USA \\ ${ }^{4}$ Department of Marine Chemistry and Geochemistry, Woods Hole Oceanographic Institution, MS\#25, \\ Woods Hole, Massachusetts 02543, USA \\ ${ }^{5}$ School of Ocean and Earth Science and Technology, University of Hawaii, 1000 Pope Road, Honolulu, Hawaii 96822, USA \\ ${ }^{6}$ Present address: Department of Marine Chemistry and Geochemistry, Woods Hole Oceanographic Institution, \\ MS\#25, Woods Hole, Massachusetts 02543, USA
}

\begin{abstract}
Previous studies have focused on the role of labile dissolved organic matter (DOM) (defined as turnover time of $\sim 1$ d) in supporting heterotrophic bacterial production, but have mostly neglected semilabile DOM (defined as turnover time of $\sim 100$ to $1000 \mathrm{~d}$ ) as a potential substrate for heterotrophic bacterial growth. To test the hypothesis that semilabile DOM supports substantial amounts of heterotrophic bacterial production in the open ocean, we constructed a 1-dimensional epipelagic ecosystem model and applied it to 3 open ocean sites: the Arabian Sea, Equatorial Pacific and Station ALOHA in the North Pacific Subtropical Gyre. The model tracks carbon, nitrogen and phosphorus with flexible stoichiometry. This study used a large number of observations, including measurements of heterotrophic bacterial production rates and standing stocks, and DOM concentration data, to rigorously test and constrain model output. Data assimilation was successfully applied to optimize the model parameters and resulted in simultaneous representation of observed nitrate, phosphate, phytoplankton and zooplankton biomass, primary production, heterotrophic bacterial biomass and production, DOM, and suspended and sinking particulate organic matter. Across the 3 ocean ecosystems examined, the data assimilation suggests semilabile DOM may support 17 to $40 \%$ of heterotrophic bacterial carbon demand. In an experiment where bacteria only utilize labile DOM, and with more of the DOM production assigned to labile DOM, the model poorly represented the observations. These results suggest that semilabile DOM may play an important role in sustaining heterotrophic bacterial growth in diverse regions of the open ocean.
\end{abstract}

KEY WORDS: Heterotrophic bacteria - Semilabile dissolved organic matter - Marine ecosystem model $\cdot$ Data assimilation

\section{INTRODUCTION}

Organic carbon is exported from the upper ocean as both particulate (POM) (Berelson 2001, Honjo et al. 2008) and dissolved organic matter (DOM) (Carlson et al. 1994, Ducklow et al. 1995, Hansell 2002). DOM is potentially an important form of export and is the dominant organic carbon pool in the ocean (Hedges 1992). About $50 \%$ of primary production (PP) in oceanic ecosystems is ultimately released as DOM through a variety of processes (Ducklow \& Carlson 1992, Williams 2000). DOM is mostly utilized by heterotro- 
phic Bacteria and possibly also Archaea (hereafter we functionally describe both groups as 'bacteria') (Azam 1998), with a major fraction of the utilized DOM respired to $\mathrm{CO}_{2}$ (del Giorgio \& Cole 2000, Robinson 2008), and with a lower fraction assimilated into biomass and ultimately reintroduced to the plankton food web or lysed by viruses (Azam et al. 1983). Bacterial activity also regenerates inorganic nutrients from DOM, which in turn directly impacts PP. Thus bacteria are a key component of the oceanic carbon cycle.

The marine DOM pool represents a broad continuum in terms of its biological reactivity (Carlson 2002), from refractory material turning over on time scales of millennia to labile material turning over on time scales of minutes to days, and semilabile material with intermediate turnover times of months to a few years. Most previous studies have tended to focus on labile DOM (LDOM) compounds such as dissolved free amino acids and monosaccharides (Kirchman 2002 and references therein) as the major food sources for bacteria in the ocean, largely neglecting the role of semilabile DOM (SDOM) in supporting microbial growth. By definition, SDOM is also biologically active, although at a lower rate than LDOM. Since the bulk concentration of SDOM is much higher than that of LDOM in open ocean (Carlson 2002), SDOM has the potential to support a substantial amount of bacterial production (Jackson 1988).

Since Redfield (1934) concluded that the elemental composition of marine seston is relatively stable in the world ocean (Redfield ratio, molar ratio of $\mathrm{C}: \mathrm{N}: \mathrm{P}=$ 106:16:1), marine biogeochemical models have tended to use one of these elements as currency (usually N) to trace plankton dynamics, assuming that other elements generally track proportionally to this currency at the Redfield ratio. However, various studies suggest flexible biomass stoichiometry may be needed to accurately represent heterotrophic microbial dynamics in the sea. The elemental composition of heterotrophic bacteria differs markedly from phytoplankton (Kirchman 2000 and references therein), with bacterial biomass frequently enriched in $\mathrm{N}$ and $\mathrm{P}$ relative to phytoplankton. Moreover, although variable in space and time, bulk pools of DOM appear to be depleted in N and P (Benner 2002) and bacterial growth appears directly affected by DOM stoichiometry. Variability in DOM stoichiometry may derive from alteration in sources or sinks of specific substrates; for example, phytoplankton production of C-enriched DOM has been shown to occur under nutrient-limiting conditions (Fogg 1966, Bjørnsen 1988, Nagata 2000). Alternatively, selective removal of $\mathrm{N}$ - and P-enriched DOM substrates by bacteria also controls bulk DOM pool stoichiometry (Hopkinson \& Vallino 2005). Such nonRedfield dependent DOM production and removal mechanisms present major challenges for models of bacterial growth dynamics.

Numerical modeling of bacterial dynamics in the open sea is a new and important approach for generating and testing hypotheses regarding the role of bacteria in ocean carbon and nutrient cycling. Data assimilation provides a valuable tool to handle the increasing number of observations of bacterial dynamics emerging from recent oceanographic studies. Data assimilation methods seek to minimize differences between modeling results and observations by objectively optimizing model parameters (Lawson et al. 1995, Vallino 2000, Spitz et al. 2001, Friedrichs 2002, Ward et al. 2010). As field measurements are expensive and difficult, usually only a small number of the state variables and rates in a given model are directly measured. Data assimilation uses available observations to improve confidence in other unknown variables and rates.

We constructed a marine ecosystem model to test the hypothesis that a significant portion of bacterial production is supported by SDOM in the open ocean. In this study, LDOM are those with turnover time of $\sim 1 \mathrm{~d}$, and SDOM are those with turnover time of $\sim 100$ to $1000 \mathrm{~d}$ depending on site, time and space. The model emphasizes detailed heterotrophic microbial dynamics and follows carbon $(\mathrm{C})$, nitrogen $(\mathrm{N})$ and phosphorus (P) of the state variables with flexible stoichiometry. The model was then applied to a 1-dimensional (1-D) framework at 3 open ocean sites in the North Pacific Subtropical Gyre, Arabian Sea and Equatorial Pacific. The comparison of the 3 study sites in different open ocean regions is used to reveal general patterns in the open ocean controlled by regional-scale processes. Data assimilation was conducted to minimize the misfits between the model and observations through optimizing the model parameters. By this approach, the model was constrained by available data from different aspects of each ecosystem, including concentrations and/or rates related to nutrients, phytoplankton, zooplankton and particulate organic matter (POM), as well as bacteria and DOM.

\section{METHODS}

The ecosystem model. The ecosystem model simulates flows and stocks of $\mathrm{C}, \mathrm{N}$ and $\mathrm{P}$ through each of the state variables including: generic phytoplankton (PHY), $\mathrm{N}_{2}$-fixing Trichodesmium spp. (TR) and unicellular diazotrophs (UN), heterotrophic bacteria (BA), protozoan (PRT) and metazoan (MZ) zooplankton, labile (LDOM) and semilabile DOM (SDOM), particulate detritus (DET) and inorganic nutrients (ammonium, NH4; nitrate, NO3; and phosphate, PO4) (Fig. 1). Chlorophyll a of PHY, TR and UN are 


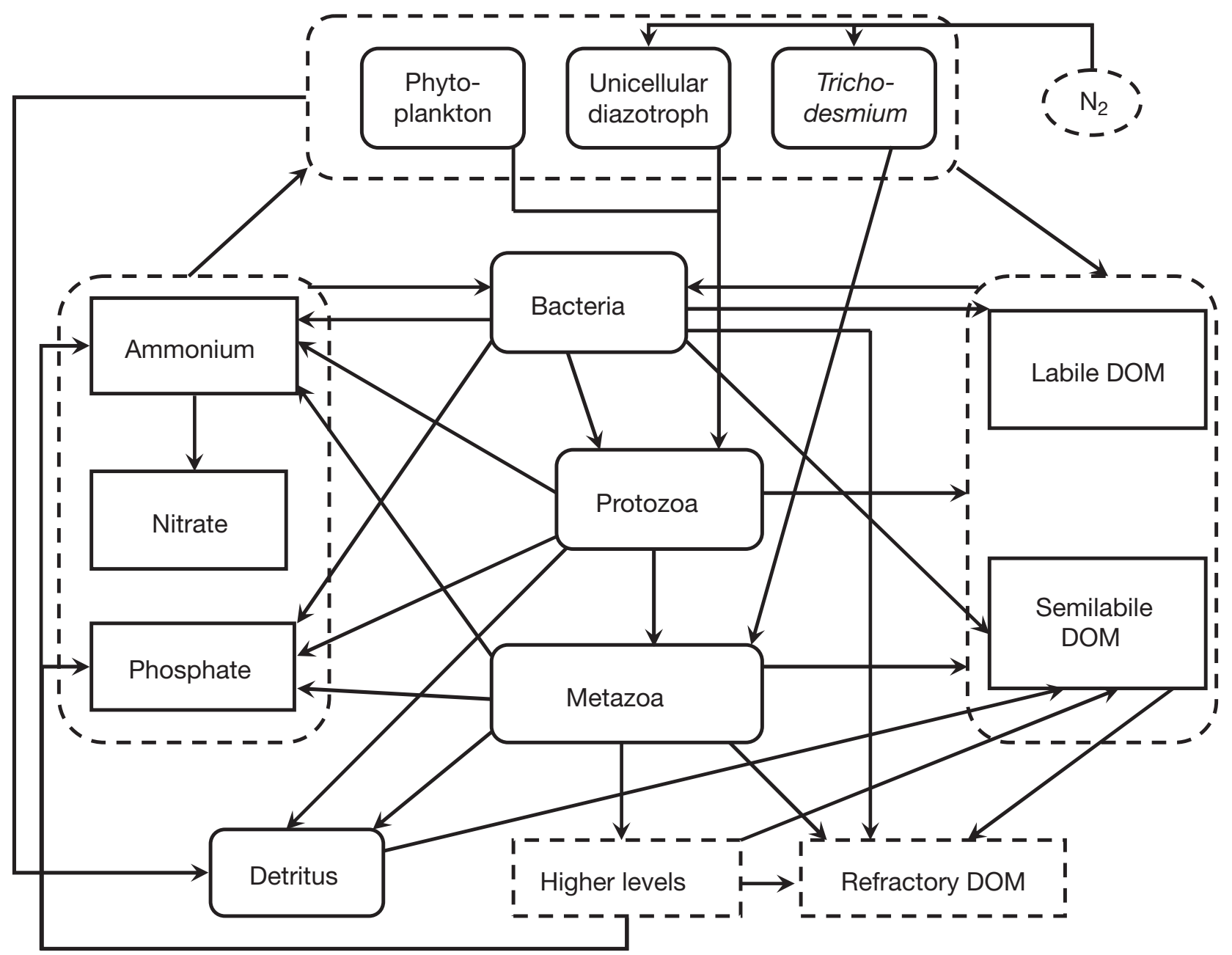

Fig. 1. Flow diagram of the model showing trophic structure and state variables. Dashed borders for ' $\mathrm{N}_{2}$ ', 'Higher levels' and 'Refractory DOM' indicate they are not explicitly modeled. Several state variables are grouped by dashed rectangles. A flow arrow ending on a grouping rectangle means the flow applies to all the state variables inside the rectangle. Unicellular diazotroph and Trichodesmium are disabled at the AS (Arabian Sea) and EQP (equatorial Pacific) sites

also simulated independently from biomass. Higher trophic levels (those higher than PRT and MZ) are implicitly represented in order to close the model. Refractory DOM is also implicitly represented as loss terms for some state variables. Table 1 lists all the state variables and their abbreviations, as well as the tracked components ( $\mathrm{C}, \mathrm{N}, \mathrm{P}$ and/or chlorophyll a) of each variable. The $2 \mathrm{~N}_{2}$ fixing groups were disabled for the Arabian Sea and Equatorial Pacific models to reflect that $\mathrm{N}_{2}$-fixation was greatly inhibited in the model in these relatively inorganic nitrogenenriched regions.
Table 1. List of the modeled state variables. The tracked components including carbon (C), nitrogen (N), phosphorus (P) and chlorophyll a (CHL) for each state variable are marked with ' $\mathrm{X}$ '

\begin{tabular}{|llllll|}
\hline \multirow{2}{*}{ Name } & \multicolumn{5}{c|}{ Component } \\
& C & N & P & CHL & \\
& & & & \\
PHY & X & X & X & X & Non-diazotrophic phytoplankton \\
TR & X & X & X & X & Diazotrophic Trichodesmium spp. \\
UN & X & X & X & X & Diazotrophic unicellular phytoplankton \\
BA & X & X & X & & Heterotrophic bacteria \\
PRT & X & X & X & & Protozoan zooplankton \\
MZ & X & X & X & & Metazoan zooplankton \\
LDOM & X & X & X & & Labile dissolved organic matter \\
SDOM & X & X & X & & Semilabile dissolved organic matter \\
POM & X & X & X & & Particulate organic matter \\
NH4 & & X & & & Ammonium \\
NO3 & & X & & & Nitrate \\
PO4 & & & X & Phosphate \\
\hline
\end{tabular}


The model includes flexible stoichiometry for all compartments. To integrate flexible stoichiometry with the phytoplankton growth scheme, we selected the Droop equation (Droop 1974, McCarthy 1980, Droop 1983) and adopted the model of Geider et al. (1998) with some changes. Thus the model allows phytoplankton to take advantage of high light to store more carbon when ambient nutrient levels are depleted and to store more nutrients when light is low (Bertilsson et al. 2003). In addition, when the $\mathrm{N}$ or $\mathrm{P}$ quota is lower than the Redfield value, the model determines the excretion of SDOM by phytoplankton (Fogg 1966, Bjørnsen 1988, Nagata 2000), as will be discussed later.

Here we briefly describe the model schemes for heterotrophic bacterial dynamics. The full model description and equations are provided in Supplement 1 available at www.int-res.com/articles/suppl/ a060p273_supp.pdf. The heterotrophic bacterial scheme in this model has several key features as detailed here:

(1) The DOM is divided into LDOM and SDOM, which are produced by autotrophs (including PHY, TR and UN), protozoa, metazoa, bacteria, dissolving detritus and implicit higher trophic levels (Fig. 1) as follows.

To represent passive diffusion of DOM out of phytoplankton cells (Fogg 1966, Bjørnsen 1988), the phytoplankton in our model release LDOM as a first order function of phytoplankton biomass (default 5\% per day) at the same C:N:P ratio as the biomass. To represent the overflow model of DOM release (Fogg 1966, Nagata 2000), the phytoplankton in our model also excrete carbohydrate ( $\mathrm{C}$ only without $\mathrm{N}$ or $\mathrm{P}$ ) at a fixed fraction of PP (default $5 \%$ ), with the assumption that $75 \%$ of this carbohydrate excretion goes to labile dissolved organic carbon (DOC) pool and the other $25 \%$ to the semilabile DOC pool. The model also considers that phytoplankton release DOM in order to adjust their stoichiometry to approach the Redfield ratio: SDOM is excreted at high $\mathrm{C}: \mathrm{N}$ and/or $\mathrm{C}: \mathrm{P}$ ratio if phytoplankton $\mathrm{C}$ is in excess to $\mathrm{N}$ or $\mathrm{P}$. The time scale for this adjustment is $2 \mathrm{~d}$, which means this SDOM excretion will adjust the stoichiometry of phytoplankton to the Redfield ratio in $2 \mathrm{~d}$ if the rate of excretion is unchanged. For $\mathrm{N}_{2}$-fixing groups $\mathrm{TR}$ and $\mathrm{UN}$ in the model, part (by default $36 \%$ ) of their newly fixed $\mathrm{N}$ (from $\mathrm{N}_{2}$ fixation) is released equally as both labile dissolved organic nitrogen (DON) and ammonium to reflect observations (e.g. Glibert \& Bronk 1994, Mulholland et al. 2004, Mulholland 2007).

Zooplankton, including both protozoa and metazoa, release a portion of ingested organic matter as DOM via both sloppy feeding and excretion. The model does not separate these 2 processes, but assumes a certain percentage of the total grazed $\mathrm{C}$ by protozoa and metazoa is released as DOC. The ratio of released
DON or dissolved organic phosphorus (DOP) to released DOC is same as the N:C or P:C ratio of the zooplankton food source. The model then partitions the released DOC by default with $75 \%$ to the labile pool and the other $25 \%$ to the semilabile pool. In addition, the release rates of semilabile DON and DOP are adjusted accordingly if the zooplankton cellular $\mathrm{N}: \mathrm{C}$ and $\mathrm{P}: \mathrm{C}$ are different from their predefined reference ratios, which also helps zooplankton to stabilize their stoichiometry toward their reference ratios. The removal of metazoa, implicitly represented in the model as grazing by higher trophic levels, contributes to production of SDOM, remineralization of nutrients, and carbon respiration.

Both the carbohydrates release of phytoplankton and total DOC release by zooplankton are partitioned by default as $25 \%$ to the labile pool and $75 \%$ to the semilabile pools. But there is no evidence to directly support this partitioning. The uncertainty related to this partitioning will be discussed later.

Although bacteria are net DOM consumers, the firstorder mortality of bacteria also contributes to the LDOM pool in the model, which always reduces the net flux of LDOM into bacteria. The final source of DOM is from detritus, which dissolves and produces SDOM as a first-order function of detritus concentration when it sinks through the model domain. The sinking speed and the dissolution rate of detritus are controlled by optimizable parameters.

(2) The lability of SDOM is much lower than that of LDOM. The model first determines bacterial utilization of DOC by assuming available labile DOC (ALC) equals the labile DOC concentration while available semilabile DOC (ASC) only equals a portion of semilabile DOC concentration:

$$
\mathrm{ALC}=C_{\mathrm{LDOM}}, \quad \mathrm{ASC}=r_{\mathrm{SDOM}} \cdot C_{\mathrm{SDOM}},
$$

where $C_{\mathrm{LDOM}}$ and $C_{\mathrm{SDOM}}$ are concentrations of labile and semilabile DOC, and $r_{\mathrm{SDOM}}$ is an optimizable parameter controlling the lability of semilabile DOC. Then the utilization rates of labile and semilabile DOC by bacteria are computed using Monod functions respectively:

$$
\begin{aligned}
& U_{\mathrm{LDOC}}=\hat{\mu}_{\mathrm{BA}} \cdot C_{\mathrm{BA}} \cdot \frac{\mathrm{ALC}}{\mathrm{ALC}+k_{\mathrm{DOM}}+\mathrm{ASC}} \\
& U_{\mathrm{SDOC}}=\hat{\mu}_{\mathrm{BA}} \cdot C_{\mathrm{BA}} \cdot \frac{\mathrm{ASC}}{\mathrm{ASC}+k_{\mathrm{DOM}}+\mathrm{ALC}}
\end{aligned}
$$

where $U_{\mathrm{LDOC}}$ and $U_{\mathrm{SDOC}}$ are utilization rates of labile and semilabile DOC, $\hat{\mu}_{\mathrm{BA}}$ is the maximum bacterial growth rate integrating other limiting factors such as nutrients and temperature, $C_{\mathrm{BA}}$ is the bacterial carbon biomass and $k_{\text {DOM }}$ is the half-saturation concentration related to 'available' DOC. Thus, the ratio of labile to semilabile DOC utilization is determined by parameter $r_{\mathrm{SDOM}}$ in Eq. (1). 
(3) The model then determines the bacterial utilization of DON and DOP based on the computed utilization rate of DOC. Due to the high lability of LDOM, the model assumes all LDOM is used quickly and the ratio of labile DOC, DON and DOP utilization equals the $\mathrm{C}: \mathrm{N}: \mathrm{P}$ ratio of the bulk LDOM pool. However, the model considers that bacteria have the capability to use SDOM with higher $\mathrm{N}: \mathrm{C}$ and $\mathrm{P}: \mathrm{C}$ ratios than the bulk SDOM pool (Eq. 15 in Supplement 1). This mechanism allows bacteria to take up excess $\mathrm{N}$ and $\mathrm{P}$ and reduces relative nutrient contents in the SDOM pool, consistent with observations. The bacteria also take up inorganic nutrients, which alleviates nutrient limitation on bacterial growth (Eqs. 16 \& 17 in Supplement 1).

(4) Bacterial growth efficiency (BGE), the ratio of bacterial production (BP) to bacterial carbon demand (BCD, equals $\mathrm{BP}+$ bacterial respiration), normally increases with the BP as shown by del Giorgio \& Cole (2000). To reflect this observation, the portion of assimilated $\mathrm{C}$ to be respired in the model is inversely related to BCD. Thus a higher BCD results in a higher proportion of $\mathrm{BP}$ and therefore a higher BGE, and vice versa. This mechanism also impacts the remineralization rate of DOM by bacteria. When BGE is lower and more $\mathrm{C}$ is respired by bacteria, the $\mathrm{C}$ left for bacterial growth is less and therefore the bacterial requirements for nutrients ( $\mathrm{N}$ and $\mathrm{P}$ in the model) are also less. Thus, with lower BGE, nutrients are more likely in excess and therefore the remineralization rates are higher.

Study sites and modeling framework. We selected 3 open sites for our study. One site was the longterm biogeochemical observatory, Station ALOHA $\left(22.75^{\circ} \mathrm{N}, 158.00^{\circ} \mathrm{W}\right)$, the field site for the Hawaii Ocean Time-series (HOT) program, established in the North Pacific Subtropical Gyre in 1988 (Karl et al. 2001, Doney \& Ducklow 2006). The station is $100 \mathrm{~km}$ north of Oahu, Hawaii, USA with a bottom depth of $\sim 4700 \mathrm{~m}$. The station is within the southward return flow of the eastern gyre with relatively weak horizontal transport (Karl et al. 2001), and thus represents a good site to apply 1-D ecological modeling. This study site will be referred to as HOT hereafter.

For comparison, we selected other tropical/subtropical oceanic sites with available data and contrasting physical regimes in the Arabian Sea (AS) and Equatorial Pacific (EQP). US Joint Global Ocean Flux Study (JGOFS) off-shore site S7 was the selected AS site, located at $16^{\circ} \mathrm{N}, 62^{\circ} \mathrm{E}$. The EQP site is located at $0^{\circ} \mathrm{N}$, $140^{\circ} \mathrm{W}$. Because seasonal monsoons occur at the AS and strong upwelling occurs across the EQP compared to the strongly stratified condition at HOT, these 2 sites were expected to show different microbial dynamics. As the modeling framework for these 2 sites has already been set up by others (Friedrichs et al. 2006, 2007), the comparison study can be con- ducted by embedding our ecosystem model into the existing model framework, along with some recent improvements, such as assimilating bacterial and DOM data.

1-D frameworks for the upper ocean were set up based on data availability for these sites to cover years 1995 for the AS site, 1992 for the EQP site and 2002 at HOT. At the sites in the AS and the EQP, 20 layers were used to cover the upper $150 \mathrm{~m}$, with 10 surface layers of $5 \mathrm{~m}$ each and 10 bottom layers of $10 \mathrm{~m}$ each. At HOT, the framework used 25 layers, with 10 surface layers of $5 \mathrm{~m}$ each and 15 bottom layers of $10 \mathrm{~m}$ each, covering the upper $200 \mathrm{~m}$ water column. A deeper bottom was used for HOT because the observed nutrient levels at $200 \mathrm{~m}$ were much less variable than those at $150 \mathrm{~m}$. The model is forced by physical fields such as light, temperature, mixed layer depth, vertical velocity and diffusivity (see Supplement 1 for more details).

Data assimilation. A variational adjoint scheme (Lawson et al. 1995) was used for the parameter optimization process including the following procedures. (1) A cost function was constructed to evaluate the misfits between the observations and modeled results. A lower cost function indicates a better fit of the model to observations. A cost function value of less than 1.0 indicates an ideal fit of the model to observations. (2) An adjoint model was constructed for the ecosystem model using the auto-differentiation software TAPENADE 2.1 (Institut National de Recherche en Informatique et en Automatique [INRIA], France) to compute the gradients of the cost function with respect to the model parameters. (3) A limited-memory quasi-Newton optimization software M1QN3 3.1 (Gilbert \& Lemaréchal 1989) was adopted to use the computed gradients from the adjoint model to determine the direction and the optimal step size by which the model parameters need to be modified in order to reduce the cost function. These procedures were conducted iteratively until the preset criteria of low gradients of the cost function with respect to the model parameters were met. For more details of the assimilation scheme as applied to this framework, see Friedrichs et al. (2006, 2007) and also Supplement 1.

Observations to be assimilated were obtained for AS and EQP online at http://usjgofs.whoi.edu/jg/dir/jgofs/, and for HOT at http://hahana.soest.hawaii.edu/hot/ hot-dogs/interface.html. The bacterial production data at HOT were measured during some, but not all HOT cruises (Church et al. 2006).

We included as many data types as possible: up to 17 types of observations were assimilated for each site (several data types were unavailable for AS and EQP) (Table 2). The corresponding model equivalents used to compute the cost function are also listed in Table 2 for each type of the assimilated observations. For most 
Table 2. Assimilated observations and their model equivalents used for computation of the cost function. Numbers of assimilated vertical profiles are also listed. Only single points of NO3, PO4, MZc, STc, STn and STp were assimilated. Some observations are unavailable for all the sites: listed as ' 0 ' profiles assimilated. Modeling sites: AS: Arabian Sea, EQP: Equatorial Pacific, HOT: Hawaii Ocean Time-series Station ALOHA. C: carbon; N: nitrogen; P: phosphorus; DOM, DOC, DON, DOP: dissolved organic matter, carbon, nitrogen, phosphorus; DET: particulate detritus; POC, PON, POP: particulate organic carbon, nitrogen, phosphorus. See Table 1 for other abbreviations

\begin{tabular}{|c|c|c|c|}
\hline Symbol & Assimilated observation & Model equivalent & $\begin{array}{l}\text { Assimilated profiles } \\
\text { (AS, EQP, HOT) }\end{array}$ \\
\hline NO3 & Average nitrate $^{a}$ in mixed layer & NO3 at surface grid & $6,5,10$ \\
\hline $\mathrm{PO} 4$ & Average phosphate in mixed layer & PO4 at surface grid & $6,5,10$ \\
\hline $\mathrm{MZc}$ & Average mesozooplankton C biomass in surface $175 \mathrm{~m}$ & MZ C biomass at surface grid & $4,24,4$ \\
\hline PHYn & $\begin{array}{l}\text { Small phytoplankton } \mathrm{N} \text { biomass estimated from cell } \\
\text { counts of Prochlorococcus, Synechococcus and } \\
\text { pico-eukaryotes }\end{array}$ & $\mathrm{N}$ biomass of $\mathrm{PHY}, \mathrm{UN}$ & $6,8,9$ \\
\hline CHL & Chlorophyll $a$ & Chlorophyll $a$ of PHY, TR and UN & $6,8,10$ \\
\hline PP & Primary production & $\begin{array}{l}\text { Primary production of PHY, TR and } \\
\text { UN minus their DOM excretion } \\
\text { (only particulate PP) }\end{array}$ & $5,27,9$ \\
\hline BAc & Bacterial C biomass estimated from cell counts & BA carbon biomass & $5,13,9$ \\
\hline BP & Bacterial production from leucine incorporation & BA production & $4,41,3$ \\
\hline sDOC & $\begin{array}{l}\text { Semilabile DOC estimated as difference of total DOC } \\
\text { and deep-ocean DOC }\end{array}$ & SDOM carbon & $5,6,10$ \\
\hline SDON & Semilabile DON estimated similarly to DOC & SDOM nitrogen & $5,0,10$ \\
\hline sDOP & Semilabile DOP estimated similarly to DOC & SDOM phosphorus & $0,0,10$ \\
\hline POC & Suspended POC & $\mathrm{C}$ of $\mathrm{PHY}, \mathrm{TR}, \mathrm{UN}, \mathrm{PRT}$ and DET & $5,2,10$ \\
\hline PON & Suspended PON & $\mathrm{N}$ of PHY, TR, UN, PRT and DET & $5,6,10$ \\
\hline POP & Suspended POP ${ }^{\mathrm{b}}$ & P of PHY, TR, UN, PRT and DET & $0,0,10$ \\
\hline STc & $\begin{array}{l}\text { C flux collected by sediment trap } \\
\text { at depth } 800 \mathrm{~m} \text { for AS \& EQP, } 150 \mathrm{~m} \text { for HOT }\end{array}$ & $\begin{array}{l}\text { DET C flux projected at } \\
\text { observational depth }\end{array}$ & $22,20,9$ \\
\hline STn & $\mathrm{N}$ flux collected by sediment trap (same depth as STc) & $\begin{array}{l}\text { DET N flux projected at } \\
\text { observational depth }\end{array}$ & $22,20,9$ \\
\hline STp & P flux collected by sediment trap (same depth as STc) & $\begin{array}{l}\text { DET P flux projected at } \\
\text { observational depth }\end{array}$ & $0,0,9$ \\
\hline
\end{tabular}

observational types, vertical profiles were assimilated. About 5 profiles of each observational type were assimilated for AS, up to 40 profiles of each type for EQP and about 10 profiles of each type for HOT (Table 2). The differences arise from different cruise schedules at each site. Instead of vertical profiles, only one single point was assimilated for several observational types as described below. Because of the extreme difference in nutrient levels in and below the mixed layer, it is difficult for the model to fit the nutrient profiles (Friedrichs et al. 2006). In addition, the nutrient level below the mixed layer is more likely determined by physics than by biological processes and also has less influence on the PP compared to the surface nutrient level. Thus only the averaged nitrate and phosphate concentrations in the mixed layer were assimilated (not profiles). Zooplankton tows from surface to approximately $175 \mathrm{~m}$ provided the integrated biomass so only volume-averaged zooplankton biomass was assimilated. Finally, sediment trap data were only available at 1 depth per sampling date. Refer to Supplement 1 for more details.
Not all the parameters could be constrained with the available data, and thus not all were optimized. The parameters were characterized as: unoptimizable, optimized but poorly constrained because of high uncertainty, or optimized and well-constrained (see Supplement 1 for more details).

\section{RESULTS}

\section{Fit of modeling results to observations}

The data assimilation scheme minimized the cost functions, i.e. the differences between the observations and the modeled results (Table 3) by optimizing the model parameters (Table S3 in Supplement 1). Although not all the parameters were optimized and well-constrainable by assimilated observations (Table S3), the gradients of the cost functions for all parameters were low enough to indicate the model reaches at least local optima. The low gradients also revealed that the cost func- 
Table 3. Comparison of observations and modeling results and the cost function values before and after data assimilation at AS, EQP and HOT. The table gives averaged values of all the assimilated data points and their model equivalents. See Table 2 for abbreviations. All concentrations are in $\mathrm{mmol} \mathrm{m}^{-3}$ except that $\mathrm{CHL}$ is in $\mathrm{mg} \mathrm{m}{ }^{-3}$; PP and BP are in mmol m $\mathrm{m}^{-3} \mathrm{~d}^{-1}$; STc, STn and STp are in $\mathrm{mmol} \mathrm{m} \mathrm{m}^{-2} \mathrm{~d}^{-1}$. Blank cells: not applicable

\begin{tabular}{|lcccccccccc|}
\hline & NO3 & PO4 & MZc & PHYn & CHL & PP & BAc & BP & sDOC \\
\hline AS & & & & & & & & & \\
Observed average & 3.4 & 0.56 & 0.79 & 0.48 & 0.36 & 1.6 & 0.74 & 0.15 & 26 \\
Modeled average & 3.2 & 0.58 & 0.60 & 0.46 & 0.35 & 1.6 & 0.74 & 0.16 & 25 \\
Cost function before & 24 & 2.1 & 5.4 & 48 & 6.2 & 150 & 8.7 & 10 & 24 \\
Cost function after & 6.8 & 1.7 & 1.4 & 38 & 4.4 & 11 & 5.5 & 7.3 & 3.1 \\
EQP & & & & & & & & & \\
Observed average & 4.9 & 0.67 & 0.23 & 0.15 & 0.23 & 0.85 & 0.48 & 0.070 & 19 \\
Modeled average & 4.01 & 0.60 & 0.20 & 0.15 & 0.21 & 0.86 & 0.37 & 0.059 & 16 \\
Cost function before & 16 & 5.8 & 18 & 81 & 87 & 290 & 7.5 & 9.7 & 49 \\
Cost function after & 4.0 & 5.3 & 5.5 & 18 & 12 & 21 & 1.3 & 3.9 & 13 \\
HOT & & & & & & & & & \\
Observed average & 0.005 & 0.031 & 0.18 & 0.08 & 0.12 & 0.38 & 0.31 & 0.046 & 33 \\
Modeled average & 0.006 & 0.008 & 0.15 & 0.10 & 0.12 & 0.38 & 0.28 & 0.046 & 20 \\
Cost function before & 27000 & 1.3 & 4.3 & 2.9 & 150 & 1500 & 21 & 3.2 & 15 \\
Cost function after & 1.3 & 1.1 & 1.4 & 1.4 & 10 & 19 & 15 & 1.8 & 1.7 \\
\hline & sDON & sDOP & POC & PON & POP & STc & STn & STp & \\
\hline & & & & & & & & & \\
\hline AS & & & 4.7 & 0.92 & & 1.1 & 0.13 & & \\
Observed average & 2.9 & & 5.0 & 0.87 & & 1.1 & 0.14 & & \\
Modeled average & 2.9 & & 5.2 & 6.1 & & 7.8 & 8.8 & & \\
Cost function before & 5.9 & & 3.9 & & \\
Cost function after & 1.7 & & 2.4 & 5.0 & & 5.4 & 4.7 & & \\
EQP & & & & & & & & & \\
Observed average & & & 2.0 & 0.49 & & 0.40 & 0.055 & & \\
Modeled average & & & 2.2 & 0.46 & & 0.38 & 0.044 & & \\
Cost function before & & & 8.9 & 59 & & 8.9 & 9.1 & & \\
Cost function after & & & 2.9 & 11 & & 2.6 & 2.8 & & \\
HOT & & & & & & & & & \\
Observed average & 2.1 & 0.10 & 1.5 & 0.22 & 0.009 & 2.7 & 0.33 & 0.009 & \\
Modeled average & 2.8 & 0.15 & 1.3 & 0.23 & 0.012 & 3.1 & 0.43 & 0.011 & \\
Cost function before & 88 & 27 & 2100 & 3500 & 94 & 130 & 216 & 0.88 & \\
Cost function after & 2.1 & 3.7 & 2.5 & 1.9 & 2.4 & 0.86 & 1.1 & 0.67 & \\
\hline
\end{tabular}

\section{Modeled heterotrophic microbial dynamics}

The modeled average carbon stocks and fluxes over the whole model domain for heterotrophic microbial dynamics, including those related to bacteria, LDOM and SDOM, are shown in Fig. 2. These stocks and fluxes are normalized to the PP for each site (stocks normalized to $1 \mathrm{~d}$ of PP) in order to compare the relative strengths of fluxes at different sites. The complete figures for all the modeled stocks and fluxes (including $\mathrm{C}, \mathrm{N}$ and $\mathrm{P}$ ) are shown in Fig. S2 in Supplement 3, available at www.int-res.com/articles/suppl/ a060p273_supp.pdf.

\section{DOM stocks and fluxes}

As shown in Fig. 2, the modeled SDOM always dominated the total DOM pool, and was 74, 80 and $230 \times$ larger than the modeled LDOM at AS, EQP and HOT respectively. In relation to $\mathrm{PP}$, LDOM concentrations were similar across the 3 sites, while SDOM concentrations varied significantly at the 3 sites. SDOM tended to accumulate at oligotrophic HOT, more than at the eutrophic AS and mesotrophic EQP. The modeled turnover time of SDOM (defined as concentration divided by influx) was long: $1100 \mathrm{~d}$

tion would not change significantly with relatively small changes in the parameters, i.e. the optimized model was not sensitive to the parameters. The full comparison of each observation to its model equivalent is included in Fig. S1 in Supplement 2, available at www.int-res.com/articles/suppl/a060p273_ supp.pdf.

The averaged observations and the averaged model equivalents through the whole model domain were mostly comparable at each of the 3 sites (Table 3). However, some variables did not fit as well as others; for example, mesozooplankton biomass at AS was significantly underestimated by the model. For the variables related to microbial dynamics, both bacterial biomass and production were slightly underestimated by the model for EQP, and semilabile DON and DOP were slightly overestimated for HOT. at HOT, but much shorter with 140 and $86 \mathrm{~d}$ at AS and EQP, respectively (Table 4). Meanwhile, the turnover times of LDOM were $\sim 1 \mathrm{~d}$ for all the 3 sites (Table 4 ).

DOM was produced in the model from multiple sources, as specified by the model equations, but the relative amounts varied from site to site, and between LDOM and SDOM (Fig. 3). Excretion by phytoplankton, protozoa and metazoa contributed to both LDOM and SDOM pools, the mortality of bacteria contributed to LDOM and dissolution of detritus contributed to SDOM (Fig. 1). The total production rates of labile DOC from all sources were 36,21 and $34 \%$ of PP at AS, EQP and HOT respectively, and the production rates of semilabile DOC were $\sim 21,21$ and $8 \%$ of PP (Fig. 3). Thus about $60 \%$ of organic matter produced by primary producers ultimately passed through the DOM pool at AS, and $40 \%$ at EQP and HOT. Note the 

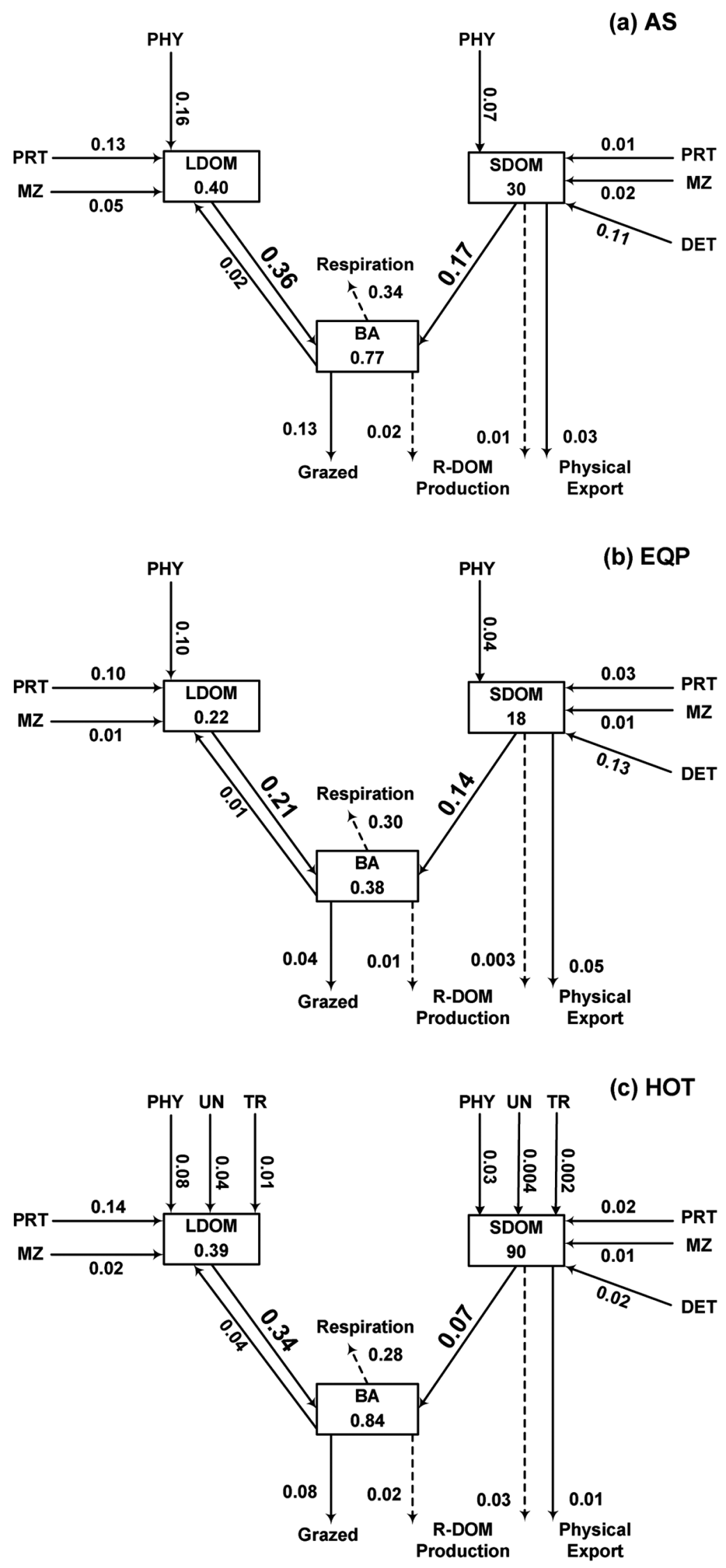

Fig. 2. Vertically and temporally averaged modeled carbon fluxes (arrows) and stocks (boxes) for heterotrophic microbial dynamics. They are normalized to primary production (stocks normalized to amount of primary production in $1 \mathrm{~d}$ ) at (a) $\mathrm{AS}$, (b) EQP and (c) HOT. 1 unit C (primary production in $1 \mathrm{~d})=0.770(\mathrm{AS}), 0.876(\mathrm{EQP})$ and 0.312 (HOT) mmol C m ${ }^{-3}\left(\mathrm{~d}^{-1}\right)$. Dashed lines: implicit loss to R-DOM. R-DOM: refractory DOM. Modeling sites: AS: Arabian Sea; EQP: Equatorial Pacific; HOT: Hawaii Ocean Time-series Station

ALOHA. For other abbreviations see Table 1

PP referred to in this section and in the discussion section includes both particulate and dissolved PP, i.e. PP producing particulate and dissolved organic matter, respectively, because DOM production by phytoplankton is a key issue of this study. The data assimilation only used particulate PP as the model equivalent to the observations, as dissolved production data were not available for these sites.

Fig. 3 shows much lower PP-normalized labile DOC production at EQP than the other 2 sites. This difference is due to the following reasons. The labile DOC in the model was produced by phytoplankton in 2 ways: (1) passive excretion which was set to $5 \%$ of phytoplankton biomass per day for all 3 sites (Table S3 in Supplement 1) and (2) active carbohydrate excretion which was the same proportion of PP for all the 3 sites and thus did not result in lower PP-normalized labile DOC production at EQP. Because the ratio of phytoplankton biomass to PP (i.e. turnover time) was similar ( 2 d) for both AS and HOT but was only $1 \mathrm{~d}$ for EQP (Fig. S2 in Supplement 3), the same $5 \%$ of biomass per day for passive labile DOC excretion equals $\sim 10 \%$ of PP at $\mathrm{AS}$ and HOT, but only equals $\sim 5 \%$ of PP at EQP. When the model partitioned DOC excretion to labile and semilabile pools, $75 \%$ of protozoan DOC excretion (ex) is assigned to labile DOC (and 25\% to semilabile DOC) at EQP, but $\sim 90 \%$ of it is assigned to labile DOC at AS and HOT (Fig. 2). Before the data assimilation the partitioning parameter $f_{\text {ex,PRT }}$ was set to default $75 \%$ for all the 3 sites. This parameter was optimized to a value of $90 \%$ for AS and HOT but could not be optimized at EQP. These results indicated that lower passive labile DOC excretion and the lower partitioning to labile DOC by protozoa 
Table 4. Average turnover time (d) of heterotrophic bacteria, LDOM and SDOM at AS, EQP and HOT in terms of carbon. Turnover time of bacteria is calculated as the ratio of biomass to bacterial production (after respiration). Turnover time of DOM is calculated by the ratio of stock to the influx of DOM. For abbreviations see Table 2

\begin{tabular}{|lccc|}
\hline & AS & EQP & HOT \\
\hline Heterotrophic bacteria & 4.4 & 6.2 & 6.4 \\
Labile DOM & 1.1 & 1.0 & 1.2 \\
Semilabile DOM & 140 & 86 & 1100 \\
\hline
\end{tabular}

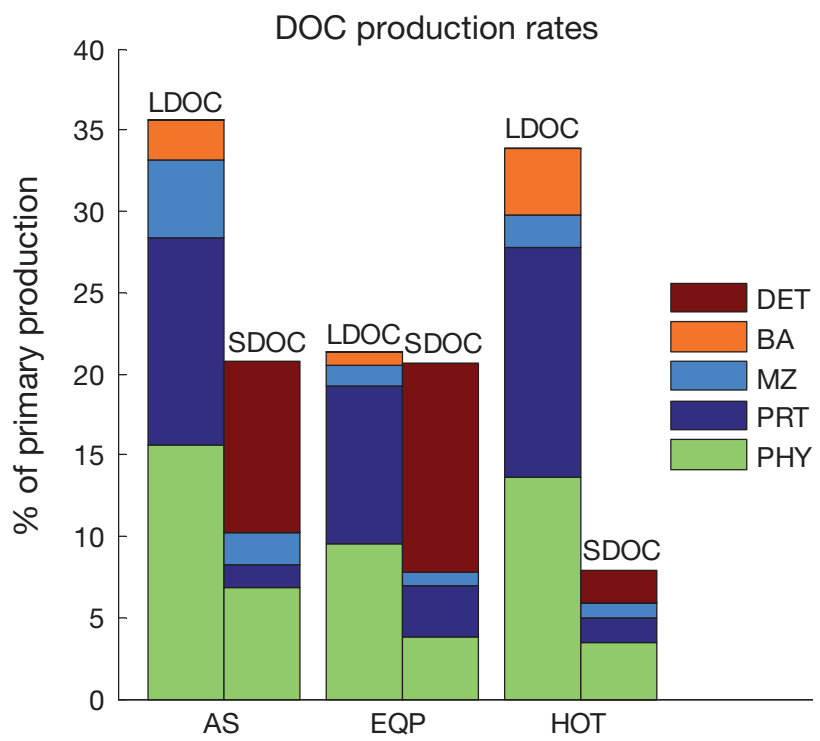

Fig. 3. Production rates of labile DOC (LDOC, left bar of each site) and semilabile DOC (SDOC, right bar of each site) from different sources relative to the (particulate plus dissolved) primary production rate at sites AS (Arabian Sea), EQP (Equatorial Pacific) and HOT (Hawaii Ocean Time-series Station ALOHA). See Table 1 for other abbreviations. The semilabile DOC production by implicit higher trophic levels is included in MZ. At HOT, DOM production by PHY also includes those from unicellular $\mathrm{N}_{2}$-fixers and Trichodesmium spp.

were likely 2 major causes of the lower PP-normalized labile DOC production at EQP.

Fig. 3 also shows much lower PP-normalized semilabile DOC production at HOT than the other 2 sites. Semilabile DOC production was dominated by detritus dissolution at AS and EQP, but the detritus dissolution was very low at HOT. Such results may not be unexpected because HOT is perennially oligotrophic and maintains the lowest rates of community production among the 3 sites studied, thus the rate of detritus production is likely low in this ecosystem. The data assimilation used observations of both concentrations (suspended organic particles) and fluxes (sediment traps) of detritus to constrain the model, improving confidence in modeled detritus production and dissolution rates. Thus, the modeled low detritus dissolution rate and therefore the low semilabile DOC production rate at HOT appear consistent with observations.

In summary, the modeled labile DOC production was higher than semilabile DOC production at AS and HOT, and was about the same as semilabile DOC production at EQP.

\section{Bacteria}

The modeled ratio of $\mathrm{BCD}$, i.e. the utilization of DOM by bacteria to $\mathrm{PP}$, was in the range of 36 to $52 \%$ (Fig. 4). Bacteria respired most of the consumed carbon and their growth efficiencies (BGE) were 34, 17 and $32 \%$ for AS, EQP and HOT respectively (Fig. 4). The resulting bacterial production (BP) ranged from 6 to $18 \%$ of PP. BGE at EQP was significantly lower than AS and HOT. As shown above, BP was constrained by observations, and the average observed and modeled BP were comparable at the sites except EQP where modeled BP was underestimated by $18 \%$. As BGE = $\mathrm{BP} / \mathrm{BCD}$, this $18 \%$ correction of BP could increase BGE to $\sim 20 \%$ at EQP, still much lower than the other 2 sites. Alternatively, BCD could be modified such that lower $\mathrm{BCD}$ at EQP would increase BGE, or increases in BCD at $\mathrm{AS}$ or HOT could reduce BGE in these systems. However, EQP has the lowest $\mathrm{BCD} / \mathrm{PP}$ ratio among the

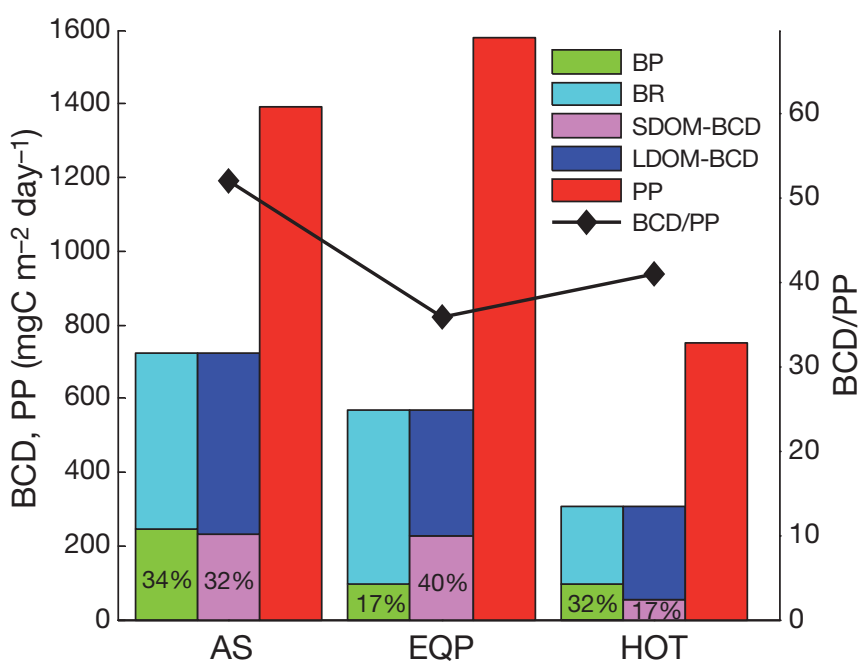

Fig. 4. Modeled bacterial carbon demand (BCD), total primary production (dissolved plus particulate, $\mathrm{PP}$, red bars) and their ratios BCD/PP (black diamonds) at the 3 sites: AS (Arabian Sea), EQP (Equatorial Pacific) and HOT (Hawaii Ocean Timeseries Station ALOHA). BCD are represented in 2 ways: (1) bacterial production (BP, green bars) plus bacterial respiration (BR, light blue bars) with the ratios of $\mathrm{BP}$ to $\mathrm{BCD}$, i.e. bacterial growth efficiency, marked; (2) SDOM- (pink bars) plus LDOM-supported BCD (dark blue bars), with the percentages of SDOM-supported BCD marked. (S)LDOM: (semi)labile dissolved organic matter 
sites (Fig. 4). Thus if the model could be adjusted to make the BGE similar at the 3 sites, it would result in even lower BCD/PP than the current low level for EQP, or would result in an even higher $\mathrm{BCD} / \mathrm{PP}$ than the current high level for AS and HOT, and the difference of $\mathrm{BCD} / \mathrm{PP}$ for the 3 sites would become even larger. The range in measured $\mathrm{BGE}$ in the ocean is large $(<1$ to $>60 \%$ ) and for the open ocean the mean measured BGE is $15 \pm 12 \%( \pm \mathrm{SD})$ (del Giorgio \& Cole 2000). BGE measurements are difficult to perform, with much uncertainty (del Giorgio \& Cole 2000 and references therein). Thus our modeled BGE values are within the observed ranges. Given that the modeled BP was constrained by observations and that our modeled derived estimates of BGE were consistent with previously published estimates, the resulting modeled DOM utilization rates by bacteria (i.e. BCD) appear reasonable.

Bacteria used both LDOM and SDOM to support their carbon demand in the model. The model predicted that SDOM supplied a substantial amount of total carbon utilization by bacteria: 32,40 and $17 \%$ for AS, EQP and HOT respectively (Fig. 4), which lent support to the key hypothesis of the present study.

\section{DISCUSSION}

After optimization by the data assimilation, the model supported the hypothesis that SDOM is an important source for the bacterial carbon requirement in the open ocean. In this section, we examine how well the modeled microbial dynamics are constrained by the data, and point out key uncertainties.

\section{Optimization of microbial dynamics}

Here we exclude other observations and consider just the SDOM concentrations and bacterial production rates to illuminate how the data assimilation constrained the microbial dynamics. This is done with reference to the conceptual scheme in Fig. 5.

First we consider the modeled total DOM production by phytoplankton and zooplankton. The modeled total DOC production by phytoplankton alone was 22, 13 and $17 \%$ of primary production for AS, EQP and HOT respectively (Fig. 3), and the modeled total DOC production by zooplankton (protozoa plus metazoa) was 25, 22 and $23 \%$ of their ingested prey organic carbon for the 3 sites (Fig. S2 in Supplement 3). Nagata (2000) concluded that in the ocean, extracellular release of DOC typically accounted for $10 \%$ of primary production, and protozoan grazers can release 20 to $30 \%$ of ingested prey organic carbon as DOC. Our modeled DOC production by phytoplankton was slightly higher than the observations and our modeled DOC production by zooplankton was within the observed range. But viral infection of host cells (phytoplankton and bacteria) could also result in substantial release of DOM (Nagata 2000), and thus the modeled DOC production by phytoplankton might be closer to reality. Overall, the modeled total DOC production rates by phytoplankton and zooplankton were comparable with general observed patterns in the ocean.

Following its release from the food web, the partitioning of DOM between its labile and semilabile components was rationalized through the model output (Step 1, Fig. 5). The model showed phytoplankton allocated 30,29 and $20 \%$ of total DOC release to semilabile DOC at AS, EQP and HOT respectively, and zooplankton allocated 16, 27 and $13 \%$ of total DOC

\section{Total DOM production}

by phytoplankton and zooplankton

(comparable to lilterature)

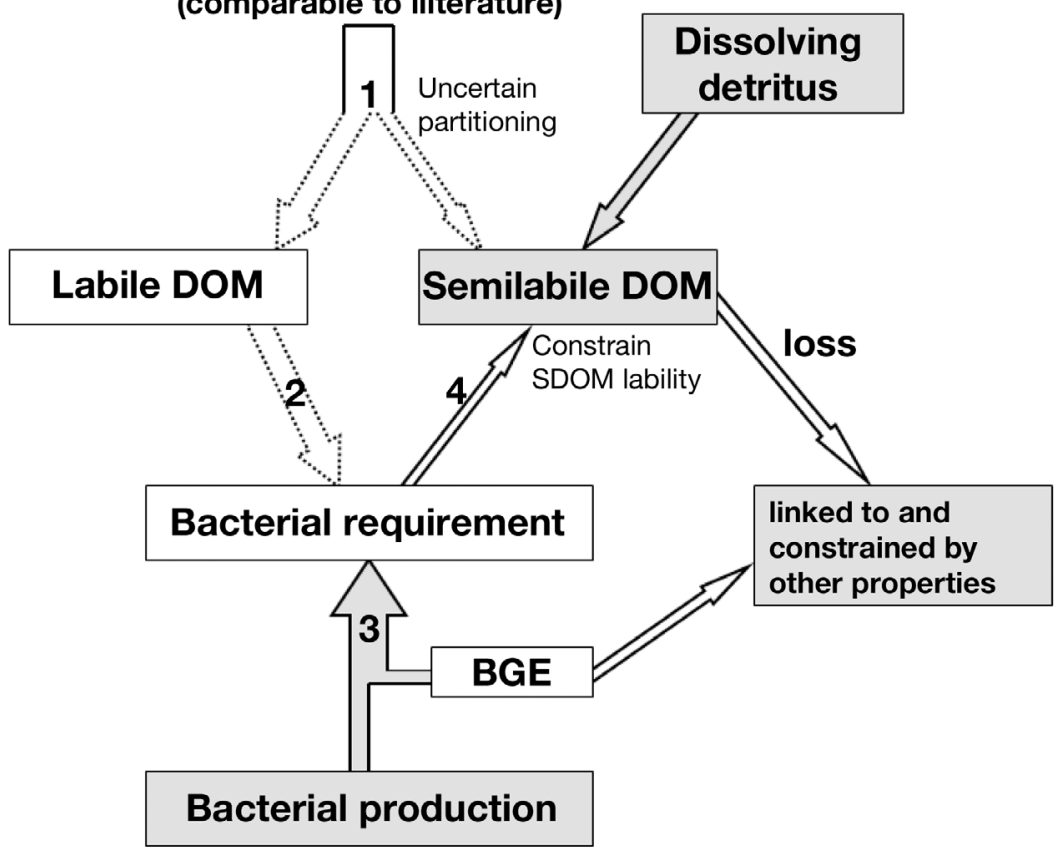

Fig. 5. Conceptual scheme showing how the modeled microbial dynamics are constrained by observations. The dashed arrows represent the fluxes that are uncertain; the shadowed boxes and arrows indicate they are directly controlled by observations. Step 1: partitioning between labile and semilabile dissolved organic matter (DOM); Step 2: all labile DOM supply to bacteria; Step 3: bacterial production and bacterial growth efficiency (BGE) determine total bacterial DOM requirement; Step 4: the unsatisfied bacterial requirement from labile DOM will be met by semilabile DOM (flux of Step 3 minus flux of Step 2). The BGE and the loss of semilabile DOM link to and can be constrained by other properties of the ecosystem 
release to the semilabile pool at the 3 sites (Fig. 3). Unfortunately there are no observations on which to compare the model performance to this partitioning.

LDOM has a very short turnover time (Table 4) and the fluxes in and out the LDOM pool were tightly coupled. The rate of LDOM utilization by bacteria was directly determined by the production of LDOM (Step 2, Fig. 5). The observations of bacterial production can be converted to a total bacterial DOM requirement using bacterial growth efficiency (BGE) (Step 3, Fig. 5), and then can act to constrain the model. However, there is uncertainty in BGE. We do not have direct constraints on BGE. However, variations in BGE affect bacterial nutrient remineralization rates, and these in turn have direct impacts on other components of the model. Thus BGE is constrained indirectly by observations like nutrient concentrations and primary production. At all 3 sites, the optimization procedure was always able to well-constrain the parameter $r_{\max , \mathrm{BA}}^{\mathrm{A}}$ (bacterial maximum active respiration rate) (Table S3 in Supplement 1), which greatly determined BGE in the model.

The total bacterial DOM requirement based on the constrained BP and BGE (Step 3, Fig. 5) needs to be met by a combination of LDOM (Step 2, Fig. 5) and SDOM. The unsatisfied bacterial DOM requirement after LDOM uptake determines the bacterial utilization rate of SDOM (Step 4, Fig. 5). The relative strength of fluxes between Steps 2 and 3 in Fig. 5 was the ultimate parameter used to test our hypothesis about the importance of SDOM for bacterial nutrition in the open sea.

The bacterial utilization rate of SDOM, together with the observations of SDOM stocks, will then be used to optimize the relative lability of the SDOM pool (Fig. 5). The lability of SDOM in the model was controlled by the parameter $r_{\mathrm{SDOM}}$, which defines the relative lability between SDOM and LDOM (Eq. 1). Initially, $r_{\mathrm{SDOM}}$ was set to $0.5 \%$ for all the 3 sites, i.e. the lability of SDOM was $0.5 \%$ of the lability of LDOM. After the data assimilation, however, $r_{\mathrm{SDOM}}$ was optimized to relatively well-constrained values of $0.68,0.87$ and $0.10 \%$ for AS, EQP and HOT respectively (Fig. 6), which resulted in average utilization times of semilabile DOC (defined as its concentration divided by its utilization rate by bacteria) of 179, 124 and $1330 \mathrm{~d}$ respectively (Table 5). From the same starting lability for SDOM, the data assimilation significantly increased the lability at AS and EQP and decreased the lability at HOT in order to better fit the assimilated observations. Although the in situ lability of SDOM was not measured, the other available observations constrained the model to different SDOM lability for the 3 sites. Because the SDOM lability equals the ratio of utilization rates to stocks of SDOM, the relatively well-con-

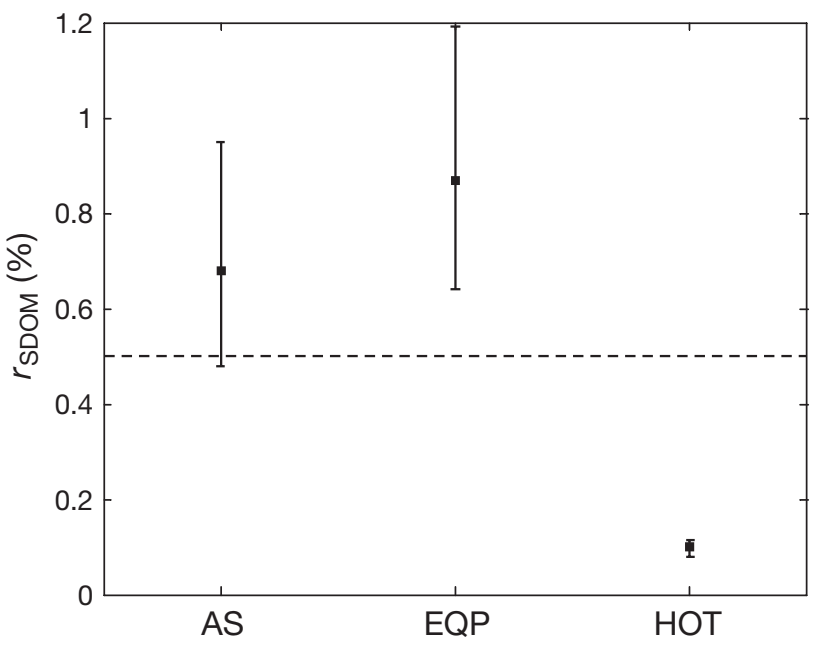

Fig. 6. Optimizing the parameter $r_{\mathrm{SDOM}}$ which defines the relative lability between labile and semilabile dissolved organic carbon (DOC) at modeling sites AS (Arabian Sea), EQP (Equatorial Pacific) and HOT (Hawaii Ocean Time-series Station ALOHA). The optimized values and their uncertainties are shown for each site. The dashed line represents the initial value of $0.5 \%$ used for all the 3 sites

Table 5. Modeled average semilabile DOC concentration, production and utilization rates at AS, EQP and HOT. Also included are sinks of semilabile DOC relative to its production rate, including bacterial utilization, physical export and conversion to refractory DOM (R-DOM). For the imbalance between semilabile DOM production and sinks (relative to production), positive imbalance indicates production exceeding than sinks in the modeled year (DOC accumulates); negative imbalance indicates sinks exceeding production and a net decline in DOC. The realized utilization time of semilabile DOC is defined as the ratio of its concentration to its utilization rate by bacteria. For abbreviations see Table 2

\begin{tabular}{|c|c|c|c|}
\hline & AS & EQP & HOT \\
\hline Concentration (mmol C m³) & 22.9 & 15.7 & 28.2 \\
\hline Production (mmol $\mathrm{C} \mathrm{m}^{-3}$ day $^{-1}$ ) & 0.160 & 0.181 & 0.0246 \\
\hline $\begin{array}{l}\text { Bacterial utilization rate } \\
\left(\mathrm{mmol} \mathrm{C} \mathrm{m} \mathrm{m}^{-3} \text { day }^{-1}\right)\end{array}$ & 0.128 & 0.126 & 0.0212 \\
\hline $\begin{array}{l}\text { Bacterial utilization/ } \\
\text { production }(\%)\end{array}$ & 79.8 & 69.6 & 86.1 \\
\hline Physical export/production (\%) & 15.4 & 26.1 & 19.0 \\
\hline $\begin{array}{l}\text { Conversion to R-DOM/ } \\
\text { production }(\%)\end{array}$ & 3.8 & 1.4 & 43.0 \\
\hline Imbalance $(\%)$ & +1 & +2.9 & -48.1 \\
\hline Realized utilization time (d) & 179 & 124 & 1330 \\
\hline
\end{tabular}

strained SDOM lability (Fig. 6), together with the directly constrained SDOM stocks, further added to our confidence in the modeled utilization rates of SDOM.

Finally, some of the SDOM production is exported by mixing or converted to refractory DOM (R-DOM) production before it can be utilized by bacteria ('loss' step, Fig. 5). A large portion of the SDOM was produced 
by dissolving detritus, whose rates were constrained by the observations as described previously. In order to fit the observed time-series of SDOM concentrations, the optimization had to adjust the term for the R-DOM production (another export of SDOM, physical export is mainly determined by physical forcing) according to the modeled SDOM utilization and production rates. This export represented a permanent loss of organic matter and nutrient elements from the surface ocean, and thus may impact the productivity of the whole system.

In summary, this scenario indicates that higher LDOM production could result in higher LDOM utilization and therefore lower SDOM utilization by bacteria, so that the percentage of SDOM-supported bacterial production would be reduced. The uncertainty related to partitioning between LDOM and SDOM from phytoplankton and zooplankton (Step 1, Fig. 5) can impact reliability of the model. However, the microbial dynamics are not an isolated subsystem in the model. From the discussion above, there were at least 2 possible ways that the microbial dynamics can link to the other processes in the model (and observations): bacterial growth efficiency and the loss of SDOM.

Thus, the microbial dynamics are partly constrained indirectly from other observations. Such considerations suggest that our hypothesis is consistent with many observations on different components of the ocean ecosystem. But the possibility still exists that an alternate solution not supporting our hypothesis can also be generated, and still be consistent with the observations. Thus we conducted another numerical experiment to test if the model can generate an alternate solution while keeping similar goodness of fit to the observations.

\section{Numerical experiment: no bacterial SDOM utilization}

Semilabile DOM does accumulate seasonally (Carlson 2002, Church et al. 2002). Such observations confirm that some phytoplankton and zooplankton do produce semilabile DOM. It remains unclear whether the accumulated semilabile DOM is mostly utilized by bacteria in the surface layer (e.g. Carlson et al. 2004), or survives eventually to be physically exported during deep-mixing events. In order to test the null hypothesis of this study, i.e. semilabile DOM mostly accumulates instead of being utilized, we conducted another numerical experiment where bacteria did not utilize any semilabile DOM. Accordingly, DOM production would be partitioned more to LDOM. Because there are no data to estimate the partitioning between
LDOM and SDOM production by phytoplankton and zooplankton, the experiment also assigned all the DOM production by protozoa and metazoa to LDOM, which could roughly reduce the total biological semilabile DOC production by $50 \%$ (Fig. 3). The scheme of semilabile DOC production from detritus dissolution was not changed, as these fluxes were partly constrained by observations. Using data assimilation to test the resulting model performance indicated that at AS, the model became much worse at fitting semilabile DOC and DON (DOP was not assimilated for AS) and bacterial biomass (reflected in their increased cost), while the fit to bacterial production remained unchanged (Fig. 7). At EQP, the model performance following assimilation was more robust at fitting semilabile DOC (DON and DOP were not assimilated for EQP), bacterial biomass and production (Fig. 7). At HOT, the model performance deteriorated in fitting semilabile DON and DOP, bacterial biomass and production, while improving only slightly in fitting semilabile DOC (Fig. 7). The total cost increased by 43,7 and $23 \%$ respectively for AS, EQP and HOT (Fig. 7). Excluding cost components for SDOM and bacterial biomass and production, the total costs from all other components increased by 26,19 and $17 \%$ respectively for AS, EQP and HOT (Table 6). Thus the experiment without SDOM utilization resulted in significantly weaker fits to both microbial observations (bacteria and SDOM) and other model components at AS and HOT. Although the experiment resulted in a better fit to bacteria and SDOM at EQP, this came at the expense of weaker fits to other observations, and the total cost still indicated overall that the experiment did not improve the model performance.

This experiment of seeking an alternate solution to our hypothesis resulted in a significantly worse fit to the observations, not just to bacterial and DOM dynamics but also to observations related to various other properties of the ecosystem (e.g. nutrient concentrations, productivity). In other words, the current model structure argues against this alternate solution to our hypothesis.

\section{CONCLUSIONS}

This is one of the first studies to use a large number of ecological and biogeochemical observations from different aspects of the upper ocean ecosystem including bacteria and DOM to test and constrain a marine ecosystem model. The modeled heterotrophic microbial dynamics were directly constrained by measured DOM concentration and bacterial biomass and production, and indirectly by other measured variables. The modeled rates and variables were inside the range of 


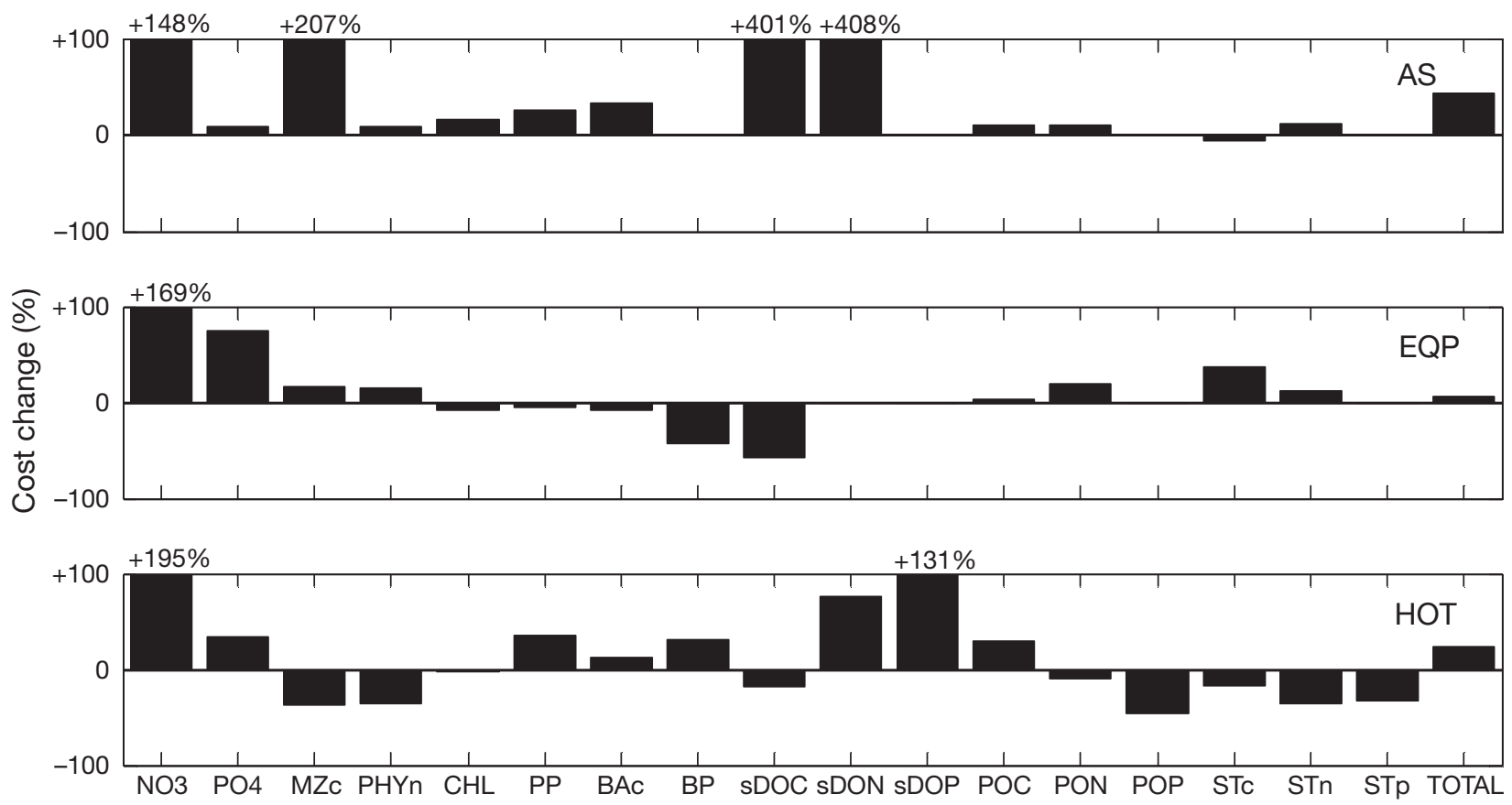

Fig. 7. Changes of cost function (including each component and total) at modeling site AS (Arabian Sea; upper panel), EQP (Equatorial Pacific; middle) and HOT (Hawaii Ocean Time-series Station ALOHA; lower) when bacteria do not utilize SDOM, and protozoa and metazoa allocate all the DOM production to the labile pool. The model was re-optimized. A positive change indicates the cost is higher and the model becomes a worse fit to the observations, and vice versa. Changes larger than $100 \%$ are marked on the top of the bars. See Table 2 for other abbreviations

Table 6. Total optimized costs excluding the semilabile DOM (SDOM) and bacterial biomass and production components, comparing the standard model and the experiments without SDOM utilization by bacteria. For abbreviations see Table 2

\begin{tabular}{|lccc|}
\hline & AS & EQP & HOT \\
\hline Standard model & 79.9 & 85.4 & 44.2 \\
No SDOM utilization & 100.8 & 101.2 & 51.5 \\
Change (\%) & +26 & +19 & +17 \\
\hline
\end{tabular}

current observations and are consistent with our current understandings of marine microbiology. By assimilating a wide range of ecosystem observations, we demonstrate that the modeled microbial dynamics did not contradict observations of the whole ecosystem. Thus this modeling work bridges heterotrophic bacteria to other parts of the upper ocean ecosystem, and provides evidence for the consistency among discrete components of ecosystems.

Our modeled results and the additional experiments did not reject our hypothesis that semilabile DOM supports a significant amount of bacterial carbon demand (17 to $40 \%$, Fig. 4). This study was applied to 3 different open ocean sites with different physical, biogeochemical and ecological characteristics: the relatively eutrophic Arabian Sea with seasonal monsoonal forc- ing, regions of the mesotrophic Equatorial Pacific where strong upwelling dominates upper ocean dynamics, and the persistently stratified oligotrophic Hawaii Ocean Time-series site. All of the sites showed similar results regarding the role of semilabile DOMsupported bacterial production. If our estimate that SDOM-supported bacterial production accounted for 17 to $40 \%$ of the total bacterial requirement is correct, SDOM is acting as a buffering pool and is likely stabilizing time-space variations in bacterial production. Such results would contribute to the observed variations in coupling between primary production and bacterial production in the open ocean.

To better support our hypothesis, the uncertainty related to partitioning between LDOM and SDOM production still needs to be clarified. We suggest further study of the components and lability of DOM produced by phytoplankton and zooplankton remain key issues for marine microbiology.

Acknowledgements. Computing resources were provided by the Sciclone cluster at The College of William and Mary. Y.W.L. was supported by fellowships from the Virginia Institute of Marine Sciences and Marine Biological Laboratory as well as NSF Grants OPP-0217282 and 0823101 to H.W.D. and VIMS and MBL, respectively. M.A.M.F.'s participation was supported in part by a grant from the NASA Ocean Biology and Biogeochemistry program (NNX07AF70G), S.C.D.'s 
participation was supported by an NSF grant to the Center for Microbial Oceanography, Research and Education (CMORE), NSF EF-0424599, and M.J.C. was supported in part by NSF grants EF-0424599 (C-MORE) and OCE 0425363. We thank all the scientists and ships' crew who collected and analyzed data during US JGOFS cruises in the Arabian Sea, Equatorial Pacific and Hawaii Ocean Time-series.

\section{LITERATURE CITED}

Azam F (1998) Microbial control of oceanic carbon flux: the plot thickens. Science 280:694-696

$>$ Azam F, Fenchel T, Field JG, Gray JS, Meyer-Reil LA, Thingstad F (1983) The ecological role of water-column microbes in the sea. Mar Ecol Prog Ser 10:257-263

Benner R (2002) Chemical composition and reactivity. In: Hansell DA, Carlson CA (eds) Biogeochemistry of marine dissolved organic matter. Academic Press, San Diego, CA, p 59-90

Berelson WM (2001) The flux of particulate organic carbon into the ocean interior: a comparison of four US JGOFS regional studies. Oceanography 14:59-67

Bertilsson S, Berglund O, Karl DM, Chisholm SW (2003) Elemental composition of marine Prochlorococcus and Synechococcus: implications for the ecological stoichiometry of the sea. Limnol Oceanogr 48:1721-1731

Bjørnsen PK (1988) Phytoplankton exudation of organic matter: Why do healthy cells do it? Limnol Oceanogr 33:151-154

Carlson CA (2002) Production and removal processes. In: Hansell DA, Carlson CA (eds) Biogeochemistry of marine dissolved organic matter. Elsevier Science, New York, NY, p 91-151

Carlson CA, Ducklow HW, Michaels AF (1994) Annual flux of dissolved organic carbon from the euphotic zone in the northwestern Sargasso Sea. Nature 371:405-408

Carlson CA, Giovannoni SJ, Hansell DA, Goldberg SJ, Parsons R, Vergin K (2004) Interactions among dissolved organic carbon, microbial processes, and community structure in the mesopelagic zone of the northwestern Sargasso Sea. Limnol Oceanogr 49:1073-1083

Church MJ, Ducklow HW, Karl DM (2002) Multiyear increases in dissolved organic matter inventories at station ALOHA in the North Pacific Subtropical Gyre. Limnol Oceanogr 47:1-10

Church MJ, Ducklow HW, Letelier RM, Karl DM (2006) Temporal and vertical dynamics in picoplankton photoheterotrophic production in the subtropical North Pacific Ocean. Aquat Microb Ecol 45:41-53

del Giorgio PA, Cole JJ (2000) Bacterial energetics and growth efficiency. In: Kirchman DL (ed) Microbial ecology of the oceans. Wiley-Liss, New York, NY, p 289-325

> Doney SC, Ducklow HW (2006) A decade of synthesis and modeling in the US Joint Global Ocean Flux Study. DeepSea Res II 53:451-458

Droop M (1974) The nutrient status of algal cell in continuous culture. J Mar Biol Assoc UK 54:825-855

Droop MR (1983) 25 years of algal growth kinetics: a personal view. Bot Mar 26:99-112

Ducklow HW, Carlson CA (1992) Oceanic bacterial productivity. Adv Microb Ecol 12:113-181

> Ducklow HW, Carlson CA, Bates NR, Knap AH, Michaels AF (1995) Dissolved organic carbon as a component of the biological pump in the North Atlantic Ocean. Philos Trans R Soc Lond B Biol Sci 348:161-167

Fogg GE (1966) The extracellular products of algae. Oceanogr Mar Biol Annu Rev 4:195-212
Friedrichs MAM (2002) Assimilation of JGOFS EqPac and SeaWiFS data into a marine ecosystem model of the central equatorial Pacific Ocean. Deep-Sea Res II 49:289-319

- Friedrichs MAM, Hood RR, Wiggert JD (2006) Ecosystem model complexity versus physical forcing: quantification of their relative impact with assimilated Arabian Sea data. Deep-Sea Res II 53:576-600

Friedrichs MAM, Dusenberry JA, Anderson LA, Armstrong RA and others (2007) Assessment of skill and portability in regional marine biogeochemical models: role of multiple planktonic groups. J Geophys Res 112:C08001. doi:10. 1029/2006jc003852

> Geider RJ, MacIntyre HL, Kana TM (1998) A dynamic regulatory model of phytoplanktonic acclimation to light, nutrients, and temperature. Limnol Oceanogr 43:679-694

Gilbert JC, Lemaréchal C (1989) Some numerical experiments with variable-storage quasi-newton algorithms. Math Program 45:407-435

Glibert PM, Bronk DA (1994) Release of dissolved organic nitrogen by marine diazotrophic cyanobacteria, Trichodesmium spp. Appl Environ Microbiol 60:3996-4000

Hansell DA (2002) DOC in the global ocean carbon cycle. In: Hansell DA, Carlson CA (eds) Biogeochemistry of marine dissolved organic matter. Academic Press, San Diego, CA, p 685-715

Hedges JI (1992) Global biogeochemical cycles: progress and problems. Mar Chem 39:67-93

Honjo S, Manganini SJ, Krishfield RA, Francois R (2008) Particulate organic carbon fluxes to the ocean interior and factors controlling the biological pump: a synthesis of global sediment trap programs since 1983. Prog Oceanogr 76:217-285

Hopkinson CS, Vallino JJ (2005) Efficient export of carbon to the deep ocean through dissolved organic matter. Nature 433:142-145

Jackson GA (1988) Implications of high dissolved organic matter concentrations for oceanic properties and processes. Oceanography 1:28-33

Karl DM, Dore JE, Lukas R, Michaels AF, Bates NR, Knap A (2001) Building the long-term picture: the U.S. JGOFS time-series programs. Oceanography 14:6-17

Kirchman DL (2000) Uptake and regeneration of inorganic nutrients by marine heterotrophic bacteria. In: Kirchman DL (ed) Microbial ecology of the oceans. Wiley-Liss, New York, NY, p 261-288

Kirchman DL (2002) The contribution of monomers and other low-molecular weight compounds to the flux of dissolved organic material in aquatic ecosystems. In: Findlay SEG, Sinsabaugh RL (eds) Aquatic ecosystems: interactive of dissolved organic matter. Academic Press, San Diego, CA, p 217-241

Lawson LM, Spitz YH, Hofmann EE, Long RB (1995) A data assimilation technique applied to a predator-prey model. Bull Math Biol 57:593-617

McCarthy JJ (1980) Nitrogen. In: Morris I (ed) The physiological ecology of phytoplankton. Blackwell, Oxford, p 191-234

Mulholland MR (2007) The fate of nitrogen fixed by diazotrophs in the ocean. Biogeosciences 4:37-51

Mulholland MR, Bronk DA, Capone DG (2004) Dinitrogen fixation and release of ammonium and dissolved organic nitrogen by Trichodesmium IMS101. Aquat Microb Ecol 37:85-94

Nagata T (2000) Production mechanisms of dissolved organic matter. In: Kirchman DL (ed) Microbial ecology of the oceans. Wiley-Liss, New York, NY, p 121-152

Redfield AC (1934) On the proportions of organic derivations 
in sea water and their relation to the composition of plankton. In: Daniel RJ (ed) James Johnstone Memorial Volume, University Press of Liverpool, p 177-192

Robinson C (2008) Heterotrophic bacterial respiration. In: Kirchman DL (ed) Microbial ecology of the oceans, 2nd edn. John Wiley \& Sons, Hoboken, NJ, p 299-334

Spitz YH, Moisan JR, Abbott MR (2001) Configuring an ecosystem model using data from the Bermuda Atlantic Time Series (BATS). Deep-Sea Res II 48:1733-1768

Vallino JJ (2000) Improving marine ecosystem models: use of

Editorial responsibility: Craig Carlson,

Santa Barbara, California, USA data assimilation and mesocosm experiments. J Mar Res 58:117-164

Ward BA, Friedrichs MAM, Anderson TR, Oschlies A (2010) Parameter optimisation techniques and the problem of underdetermination in marine biogeochemical models. J Mar Syst 81:34-43

Williams PJ le B. (2000) Heterotrophic bacteria and the dynamics of dissolved organic material. In: Kirchman DL (ed) Microbial ecology of the oceans. Wiley-Liss, New York, NY, p 153-200

Submitted: June 2, 2009; Accepted: May 17, 2010

Proofs received from author(s): July 14, 2010 